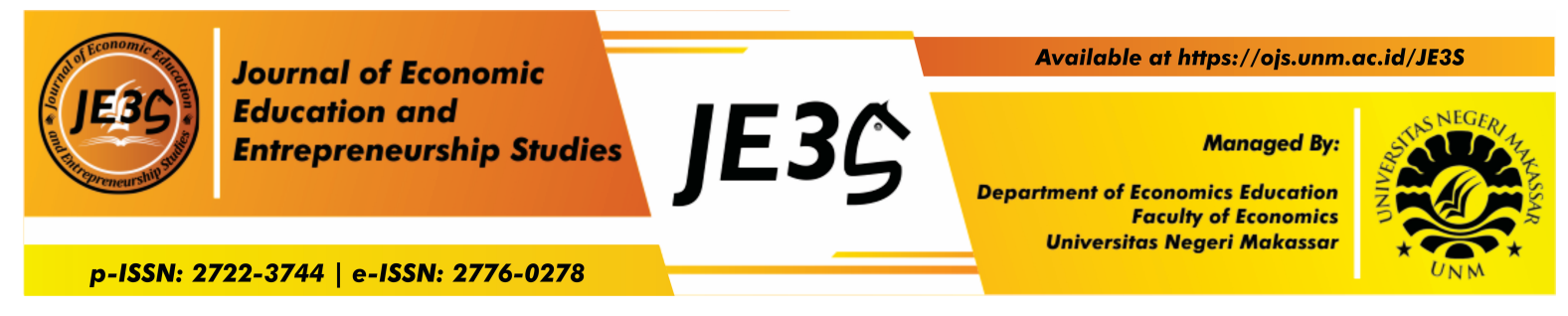

\title{
Persepsi Pengguna Jasa Transportasi Online Grab Ditinjau dari Kualitas Pelayanan
}

Muhammad Syahrul ${ }^{1}$, Nur Arisah ${ }^{2 *}$
${ }_{1,2,3}$ Fakultas Ekonomi Universitas Negeri Makassar

\begin{tabular}{l}
\hline Article History \\
\hline Received October 13, 2020 \\
Approved November 10, 2020 \\
Published December 30, 2020
\end{tabular}

\begin{tabular}{l} 
Keywords \\
\hline $\begin{array}{l}\text { Quality, Service, Transportation, Online, } \\
\text { Grab }\end{array}$
\end{tabular}

\begin{tabular}{c}
\hline JEL Classification \\
\hline L20, L21 \\
\hline
\end{tabular}

\section{How to Cite}

Syahrul, M., \& Arisah, N. 2020. Persepsi Pengguna Jasa Transportasi Online Grab Ditinjau dari Kualitas Pelayanan. Journal of Economic Education and Entrepreneurship Studies, 1(2), 88-100.

\begin{abstract}
This study aims to determine the quality of Grab online transportation services according to the perceptions of students of the Faculty Economics, in terms of the dimensions of Tangible, Reliability, Responsiveness, Assurance and Emphaty, and to find out which dimensions of service quality most influence student satisfaction in using online transportation services. This type of research is descriptive qualitative using observation, interview, and documentation techniques in data collection. The informants in this study were three people with the data analysis technique used, namely the interactive model analysis technique and the triangulation technique. The results obtained are the perceptions of users of Grab online transportation services, especially students of the Faculty of Economics, Makassar State University, are considered to be quite good. This can be seen from the various services in the application system, as well as transparent and affordable prices, and promos that are always provided by the company. They also have a friendly attitude, alertness, and the professionalism of Grab riders/drivers is quite good. It's just that there still needs to be an update to the application that must be improved, for example the reading of points/locations is sometimes incorrect and it is hoped that Grab online transportation will pay more attention to the standardization of driver/driver vehicles, as well as the need to limit working operating hours for Grab riders/drivers themselves.
\end{abstract}

\footnotetext{
*Nur Arisah

Jl. Raya Pendidikan Kampus Fakultas Ekonomi UNM

Kota Makassar, Propinsi Sulawesi Selatan, Negara Indonesia, Kode Pos 90222

e-mail: nurarisahriri@gmail.com
} 


\section{PENDAHULUAN}

Kebutuhan konsumen yang bervariasi dapat berpengaruh terhadap perubahan gaya hidup atau lifestyle. Dalam perubahan gaya hidup tersebut, konsumen akan berusaha keras untuk memenuhi kebutuhannya. Perkembangan teknologi yang semakin hari terus berkembang dan semakin canggih yang terjadi pada semua bidang kehidupan juga berdampak pada adanya keinginan mendapatkan jasa transportasi secara cepat dan mudah. Semua yang dibutuhkan dapat dengan mudah didapatkan melalui teknologi komunikasi internet dengan adanya aplikasi yang bertujuan untuk mempermudah konsumen melakukan transaksi. Kemajuan sistem transportasi telah mendorong seseorang ke arah lifesytle yang telah ditandai oleh kebebasan untuk berpindah tempat, kelancaran dalam pertukaran barang dan jasa, serta besarnya tingkat ketenagakerjaan dan mobilitas sosial yang tinggi.

Dalam lifestyle sekarang, sebagian besar masyarakat bergantung pada angkutan umum guna pemenuhan kebutuhan mobilitasnya, hal ini dikarenakan sebagian besar masyarakat memiliki tingkat ekonomi yang masih tergolong lemah dan tidak memiliki kendaraan pribadi. Jasa transportasi memiliki peranan yang sangat penting dalam kehidupan manusia, dimana transportasi digunakan setiap orang untuk dapat memperlancar aktivitasnya sehari-hari. Saat ini, usaha dalam bidang transportasi umum menjadi salah satu prospek usaha yang menguntungkan terutama pada kota-kota besar. Selain itu, sebagian besar persepsi masyarakat menggunakan transportasi umum dapat memudahkan aktivitas tanpa mengeluarkan biaya bahan bakar dan biaya lain-lain, tanpa perlu repot mengeluarkan transportasi pribadi. Namun kini, melihat adanya pengaruh globalisasi dan teknologi yang semakin canggih, sehingga menyebabkan meningkatnya kebutuhan akan seluruh lapisan masyarakat. Dengan melihat keadaan seperti itu, maka kini muncul transportasi umum berbasis online.

Semakin tingginya tuntutan mobilitas masyarakat, tentunya membutuhkan sarana transportasi yang dapat memberikan pergerakan dan perpindahan dari satu tempat ke tempat yang lain dengan cepat, walaupun jarak tempuhnya jauh. Saat ini terdapat terobosan terbaru, yakni inovasi transportasi berbasis aplikasi online yang didukung oleh teknologi komunikasi. Melalui smartphone transportasi berbasis aplikasi online ini merupakan penggabungan dari segi jasa transportasi ojek dan teknologi komunikasi. Perkembangan bisnis jasa trasportasi online yang memanfaatkan teknologi informasi akan dapat memberikan kemudahan kepada para pengguna jasa transportasi dalam hal pemesanan yang dapat dilakukan hanya dengan menggunakan smartphone. Selain jasa dan teknologi komunikasi, transportasi berbasis aplikasi online juga dilengkapi dengan fitur Global Positioning System (GPS) untuk memberikan informasi keberadaan pengemudi dan pengguna dengan rute terdekat.

Dalam kehidupan masyarakat yang membutuhkan pergerakan dan perpindahan disetiap berbagai aktivitasnya, maka membutuhkan sarana transportasi yang mendukung. Sifat dari masyarakat kota, pada umumnya adalah dinamis, selalu bergerak dan menyesuaikan diri dengan perubahan-perubahan atau keadaan yang ada. Begitu pula dengan perubahan pada pemilihan moda transportasi untuk melakukan pergerakan dari satu tempat ke tempat yang lain. Dalam menggunakan transportasi berbasis aplikasi online, terdapat beberapa point yang membedakan dari transportasi konvensional, seperti masyarakat dapat menggunakan jasa transportasi online kapan saja dan dimana saja, karena dapat diakses selama 24 jam, sehingga 
memberikan kemudahan mobilisasi dan dapat meningkatkan mobilitas seseorang, menjadi solusi saat terjadi kemacetan, dan keamanan transportasi ojek online yang terjamin.

Perusahaan jasa angkutan umum yang memanfaatkan teknologi dengan menggabungkan antara internet dan transportasi, yaitu jasa transportasi online Grab yang kini telah hadir di berbagai kota di Indonesia. Transportasi online Grab merupakan pelopor bisnis ekonomi kreatif yang memanfaatkan teknologi informasi dan komunikasi (TIK). Perubahan model transportasi dari konvensional ke transportasi berbasis aplikasi pada smartphone, sangat diminati masyarakat dan ini merupakan suatu bentuk perubahan sosial masyarakat yang menghendaki kemudahan dalam penggunaan moda transportasi. Grab telah dipercaya oleh pelanggannya dalam membantu berbagai aktivitas, bahkan perusahaan ini menjadi perusahaan jasa berbasis aplikasi pilihan utama masyarakat di kota dan saling berkompetisi secara ketat satu sama lainnya.

Sebagai penyedia jasa berbasis aplikasi, umumnya karakteristik pelanggan transportasi online Grab adalah remaja atau anak muda dengan kisaran umur 15 tahun sampai dengan 30 tahun, karena mereka yang dinilai lebih cepat paham akan perkembangan zaman dan lebih cepat menyesuaikan diri dengan hal-hal yang baru. Pengguna transportasi online khususnya Grab banyak dijumpai pada area kampus atau universitas, dimana penggunanya merupakan mahasiswa, salah satunya berada di Fakultas Ekonomi Universitas Negeri Makassar.

Untuk memenuhi kebutuhan akan jasa transportasi, perlu adanya penyedia jasa yang memberikan pelayanan yang baik dan inovatif. Untuk mendapatkan loyalitas para pelanggan perusahaan harus memiliki strategi pemasaran yang baik dan tepat agar memengaruhi loyalitas pelanggannya. Faktor-faktor yang memengaruhi loyalitas pelanggan yang diberikan, kepuasan yang didapatkan dan dirasakan oleh pelanggan, nilai yang difikirkan oleh pelanggan. Suatu perusahaan yang mampu memberikan pelayanan yang baik kepada pelanggan akan membuat citra positif bagi perusahaan. Pelayanan yang baik mendorong minat pelanggan untuk menggunakan kembali jasa tersebut sehingga tercipta loyalitas. Perusahaan yang menjualkan jasa berarti menjualkan produknya dalam bentuk kepercayaan. Memberikan pelayanan terbaik untuk konsumen menjadi tolak ukur keberhasilan sebuah perusahaan. Perusahaan yang berhasil memasarkan produk atau jasanya kepada konsumen dengan pelayanan yang memuaskan mendapatkan brand yang baik dimata konsumen. Pelayanan yang dimaksud termasuk dari pelayanan sewaktu menawarkan produk atau jasa, pelayanan ketika memberikan jasa, pelayanan atas resiko yang terjadi saat memberikan jasa dan pelayanan lain sebagainya.

Loyalitas pelanggan juga dapat terbentuk dari kepuasan yang dirasakan adalah perasaan senang ataupun kecewa yang muncul setelah menggunakan jasa tersebut. Pelanggan akan merasa senang dan kecewa setelah membandingkan kinerja atau hasil produk yang difikirkan terhadap kinerja (hasil) yang diharapkan. Dalam artian lain, seseorang merasa puas apabila hasil yang didapat minimal mampu memenuhi harapannya, sedangkan seseorang merasa tidak puas apabila hasil yang didapat tidak mampu memenuhi harapannya. Kepuasan yang dirasakan seseorang akan memberikan dampak terhadap perilaku pengguna kembali secara terusmenerus sehingga terbentukla loyalitas. Memberikan kepuasan kepada konsumen dalam memenuhi kebutuhan, keinginan serta harapan mereka merupakan hal terpenting bagi perusahaan untuk menghadapi persaingan.

Salah satu untuk merebut pangsa pasar adalah memperoleh konsumen 
sebanyak-banyaknya. Kenyamanan dan keamanan juga menjadi faktor dalam meraih konsumen. Perusahaan akan berhasil memperoleh pelanggan dalam jumlah yang banyak apabila dinilai dapat memberikan kepuasan bagi konsumen. Konumen yang merasa puas dan menjadi konsumen setia akan merekomendasikan dari mulut ke mulut. Setiap konsumen ingin mendapatkan pelayanan terbaik dari perusahaan yang menawarkan jasa kepadanya, dengan pelayanan yang baik dari penawar jasa maka konsumen akan merasa puas.

Adapun tujuan dari artikel ini yaitu bertujuan untuk mengetahui kualitas pelayanan jasa transportasi online Grab menurut persepsi mahasiswa Fakultas Ekonomi, ditinjau dari dimensi Bukti Fisik (Tangible), Keandalan (Reliability), Daya Tanggap (Responsiveness), Jaminan (Assurance) dan Empati (Emphaty). Serta untuk mengetahui dimensi kualitas pelayanan mana yang paling memengaruhi kepuasan mahasiswa dalam menggunakan jasa transportasi online Grab.

\section{METODE}

Kajian ini merupakan kajian deskriptif dengan pendekatan kualitatif. Dimana yang dicari adalah pemahaman atas fenomena sosial, sehingga yang menjadi fokus utama adalah pemahaman atas gejala sosial dalam sudut pandang subyek kajian. Kajian deskriptif kualitatif merupakan kajian yang bertujuan untuk menggambarkan dan mendeskripsikan peristiwa maupun fenomena yang terjadi di lapangan dan menyajikan data secara sistematis, faktual, dan akurat mengenai fakta-fakta atau fenomena-fenomena yang terjadi di lapangan.

Kajian deskriptif kualitatif bertujuan untuk menggambarkan, menerangkan, menjelaskan, dan menjawab secara lebih rinci permasalahan yang akan diteliti dengan mempelajari semaksimal mungkin seorang individu, suatu kelompok atau suatu kejadian. Dalam kajian kualitatif, manusia merupakan instrumen dan hasil penulisannya berupa kata-kata atau pernyataan yang sesuai dengan keadaan sebenarnya. Adapun sampel dalam kajian ini yaitu mahasiswa Prodi Pendidikan Ekonomi di Fakultas Ekonomi Universitas Negeri Makassar yang menggunakan jasa transportasi online Grab. Teknik analisis data yang digunakan dalam kajan ini adalah analisis model interaktif dan perlu dilakukan analisis data melalui reduksi data.

\section{HASIL DAN DISKUSI}

Analisis data secara deskriptif mendeskripsikan hasil analisis terhadap informan dengan cara menguraikan tanggapan responden berkaitan dengan persepsi pengguna jasa transportasi online Grab yang ditinjau dari kualitas pelayanan studi pada mahasiswa pengguna Grab di Fakultas Ekonomi Universitas Negeri Makassar. Berdasarkan data dari hasil wawancara yang telah dilakukan, peneliti akan menjelaskan dan memaparkan data yang telah diperoleh melalui wawancara secara mendalam yang dilakukan kepada para informan, yaitu sebagai berikut:

Informan pertama, menurut Syarif identitas dari pengendara/pengemudi transportasi online Grab sudah sangat memadai dibuktikan dengan identitas pengendara/pengemudi grab yang tertera pada aplikasi yaitu nama pengendara/pengemudi Grab dan plat kendaraan serta tipe/jenis kendaraan yang digunakan. Sedangkan dari segi atribut yang digunakan pengendara/pengemudi Grab juga sudah memadai dibuktikan dengan jaket dan helm pengendara GrabBike yang 
didominasi warna hijau. Menurut Syarif dari segi kondisi kendaraan yang digunakan oleh pengendara/pengemudi transportasi online Grab, masih terdapat beberapa kendaraan yang menurutnya kurang baik untuk digunakan. Hal ini dibuktikan dengan kejadian yang pernah Syarif alami ketika bepergian menggunakan GrabBike, terkadang motor yang digunakan mengalami kebocoran ban.”

Penampilan pengendara/pengemudi Grab yang dapat memengaruhi pelayanan dan memberikan kesan penilaian bagi pengguna Grab. Menurut Syarif kesan pertama yang memberikan penilaian adalah dilihat dari segi penampilan pengendara/pengemudi transportasi online Grab itu sendiri. Syarif sendiri sangat menyukai orang-orang yang berpenampilan rapi ketika sedang bekerja. Saat menggunakan GrabBike, Syarif terkadang menemukan pengendara yang menggunakan celana tidak sampai pada mata kaki, menurut Syarif seorang pengendara roda dua (motor) hendaknya menggunakan celana panjang/jeans karena ketika mengalami hal yang tidak diinginkan seperti terjatuh dari motor, setidaknya area kaki dapat terlindungi oleh celana panjang yang digunakan. Kejadian tersebut juga sempat mengalami Syarif sebagai pengendara roda dua (motor), ketika sedang keluar Syarif tidak menggunakan celana panjang dan ketika ditengah perjalanan, ia mengalami kecelakaan tunggal dan mengakibatkan area pada kakinya luka-luka. Dari kejadian itu, Syarif memiliki pengalaman tentang pentingnya memerhatikan penampilan ketika hendak berkendara.

Tipe/jenis kendaraan yang digunakan oleh pengendara/pengemudi Grab yang menjadi daya tarik pengguna Grab. Menurut Syarif sejauh ini tipe/jenis kendaraan yang digunakan oleh pengendara/pengemudi Grab yang menjadi daya tarik konsumen tidak memengaruhi dirinya sebagai pengguna transportasi online Grab. Menurut Syarif apapun tipe/jenis kendaraan yang digunakan oleh pengendara/pengemudi Grab itu sendiri, tidak menimbulkan unsur daya tarik bagi dirinya, intinya ia dapat sampai ketujuan dengan selamat.

Menurut Syarif sampai saat ini aplikasi Grab sudah sangat akurat, hal ini dibuktikan dengan penentuan lokasi yang sebelumnya tidak dapat terbaca, kini dapat terbaca setelah diperbarui. Sedangkan untuk pelayanan jasanya dari segi aplikasi juga sudah sangat membantu, hal ini dibuktikan ketika ia memesan GrabFood. Pada aplikasi itu sendiri memberikan pilihan berupa jenis makanan yang diinginkan dan juga tertera catatan jika Syarif ingin menambahkan menu/porsi makanan yang tidak terbaca pada menu aplikasinya.

Pengendara/pengemudi mentaati peraturan/tata tertib dalam berlalu lintas. Selama menggunakan GrabBike dan GrabCar, Syarif tidak pernah menemukan pengendara/pengemudi transportasi online Grab yang ugal-ugalan dalam berkendara. Menurut pengalaman Syarif sebagai pengguna Grab, ia kerap mendapatkan pengendara/pengemudi transportasi online Grab yang kurang cepat dalam melayani. Hal tersebut dapat Syarif maklumi karena ketika ia memesan GrabFood disuatu restoran atau warung makan, pengendara GrabFoodnya menelfon Syarif bahwa pesanannya datang terlambat dikarenakan banyaknya orderan yang masuk pada restoran/warung makan tersebut. Menurut Syarif, selama menggunakan layanan transportasi online Grab, kesigapan/ketepatan pengendara/pengemudinya sudah sangat baik. Hal ini dibuktikan ketika Syarif menggunakan layanan GrabExpress, barang yang diantarkan tidak memakan waktu yang lama selama dalam perjalanan. Menurut Syarif cepat atau lambatnya respon dari pihak manajemen aplikasi Grab, tergantung dari kendala yang dialami oleh pengguna layanan. Dan sejauh ini pihak manajemen aplikasi Grab sudah memberikan solusi yang dapat diterima olehnya 
sebagai pengguna transportasi online Grab, hal ini dapat dibuktikan ketika Syarif memberi penilaian terhadap salah satu pengendara yang menurutnya kurang baik dalam memberi pelayanan dan pihak manajemen aplikasi Grab merespon dan memberi solusi untuk memperbaiki dan membangun pelayanan yang memuaskan bagi pengguna transportasi online Grab kedepannya.

Selama menggunakan layanan transportasi online Grab, Syarif tidak merasa terbebani dengan biaya yang sudah ditetapkan oleh pihak Grab. Menurut Syarif jauh dan dekatnya layanan tergantung dari jarak tempuhnya. Selama ini Syarif menggunakan layanan GrabBike ketika hendak bermain futsal pada malam hari, jarak dari rumah Syarif dan lokasi futsal tidak terlalu jauh, maka dari itu Syarif sering menggunakan layanan GrabBike yang biayanya terjangkau. Apalagi Syarif juga menggunakan dompet virtual Grab yaitu OVO, dengan menggunakan OVO ketika menggunakan layanan transportasi online Grab, biayanya lebih murah lagi, dibandingkan dengan tidak menggunakan OVO. Menurut Syarif untuk setiap pekannya, pihak manajemen Grab kerap kali memberikan promo/potongan harga baik dari segi layanan GrabBike, GrabCar dan GrabFood, yang menurut Syarif promo tersebut tentu menjadi daya tarik bagi dirinya sebagai pengguna layanan Grab. Sebagai pengguna transportasi online Grab, Syarif sangat mengandalkan sikap professionalism pengendara/pengemudi Grab ketika sedang melayani. Karena menurut Syarif sikap profesionalisme dapat membangun kepercayaan antara pengguna dan pengendara/pengemudi transportasi online Grab. Mengenai sikap, Syarif berpendapat bahwa sikap setiap orang itu berbeda-beda, ada yang ramah dan ada juga yang pendiam. Ketika Syarif menggunakan layanan GrabBike, terkadang ia menemukan pengendara Grab yang hanya diam saja tanpa banyak perkataan atau basa-basi, dan terkadang ia juga mendapati pengendara GrabBike yang super ramah dan selama perjalanan mereka bercerita satu sama lain.

Menurut Syarif sebagai pengguna transportasi online Grab, ia menginginkan tampilan pada aplikasi Grab yang lebih unik sehingga memberikan penilaian yang menarik dimata pengguna Grab itu sendiri. Menurut Syarif pembatasan jam operasional tidak usah diberlakukan bagi pengendara/pengemudi Grab, dikarenakan masing-masing pengemudi/pengendara Grab memiliki target harian yang mesti dicapai, jadi kelonggaran waktu mesti diberlakukan bagi pengendara/pengemudi Grab guna memenuhi target harian.

Informan kedua, menurut Khaedar identitas dari pengendara/pengemudi transportasi online Grab sejauh ini masih kurang memuaskan, hal tersebut dibuktikan ketika Khaedar menggunakan layanan GrabBike, ketika memesan melalui aplikasi otomatis tanda pengenal dari pengendara GrabBike akan muncul seperti nama/identitas pengendara dan tipe/jenis kendaraan yang digunakan, tetapi ketika sudah menemui saya selaku pelanggan, pengendara yang identitasnya sudah tercantum pada aplikasi sangat berbeda dengan yang akan melayani, selain itu ada pula tipe kendaraan dan plat yang digunakan juga berbeda yang ada pada aplikasi dan yang akan digunakan. Untuk atributnya sendiri, menurut Khaedar sudah cukup memadai dari segi jaket dan helm yang digunakan oleh pengendara GrabBike, apalagi disaat pandemi saat ini, ia kerap mendapatkan pengendara GrabBike yang secara cuma-cuma memberikan masker untuk digunakan selama perjalanan.

Menurut Khaedar dari segi kondisi kendaraan yang digunakan oleh pengendara/pengemudi transportasi online Grab, sejauh ini juga sudah cukup baik, apalagi saat ini sudah banyak pengendara GrabBike yang memakai kendaraan roda dua (motor) matic. Selama menggunakan transportasi online Grab terutama GrabCar, 
Khaedar pernah mendapatkan pengemudi yang dapat dikatakan sangat rapi dari segi penampilan pengemudi itu sendiri dan segi kendaraan roda empat (mobil) yang sangat bersih baik dari luar maupun dari dalam, menurut Khaedar hal tersebut memberikan kesan penilaian bagi dirinya kepada pengendara GrabCar tersebut. Menurut Khaedar, tipe/jenis kendaraan yang digunakan oleh pengendara/pengemudi Grab yang menjadi daya tarik konsumen tidak memengaruhi dirinya sebagai pengguna transportasi online Grab. Apapun tipe/jenis kendaraan yang digunakan oleh pengendara/pengemudi Grab itu sendiri, tidak menimbulkan unsur daya tarik bagi dirinya sebagai pengguna transportasi online Grab.

Menurut Khaedar sejauh ini aplikasi Grab sudah sangat memenuhi kebutuhannya, hal ini dibuktikan dengan adanya layanan GrabFood dengan berbagai macam pilihan restoran/warung makan dan berbagai macam menu makanan maupun minuman yang tersedia pada aplikasi Grab itu sendiri. Selama menggunakan transportasi online Grab, Khaedar sering kali menemukan pengendara GrabBike yang menerobos lampu merah. Menurut Khaedar, kemungkinan pengendara GrabBike tersebut terburu-buru ketika sedang mendapat orderan. Padahal berhati-hati dalam berkendara merupakan kunci utama keselamatan baik bagi pengendara/pengemudi transportasi online Grab. Menurut pengalaman Khaedar sebagai pengguna GrabCar, ia kerap mendapatkan pengemudi yang lambat tiba di lokasi penjemputan. Menurut penuturan pengemudi GrabCar tersebut, ia lambat tiba dilokasi penjemputan dikarenakan padatnya lalu lintas di lokasi tertentu yang disebabkan juga oleh lampu merah.

Selama menggunakan layanan transportasi online Grab, khususnya layanan GrabFood, ketika ingin mengubah pesanan yang terlanjur telah dipesan, pengendara langsung sigap dalam merespon hal ini dapat dibuktikan ketika ia memesan makanan yang ingin diganti, pengendara GrabFood langsung menghubungi Khaedar untuk menanyakan pesanan yang ingin diubah. Selama menggunakan aplikasi dan layanan Grab, Khaedar pernah mengalami kendala pada saat akun Grabnya bermasalah. Hal ini dibuktikan ketika ia lupa password akun Grabnya, dan Khaedar langsung menghubungi pihak manajemen aplikasi Grab. Selama membahas permasalahan yang dialami, pihak manajemen aplikasi Grab hanya memberikan solusi untuk membuat akun Grab yang baru. Menurut penuturan Khaedar ini juga menjadi kesalahannya karena ia juga lupa password emailnya yang langsung disambungkan dengan aplikasi Grab.

Penggunaan layanan GrabBike yang terbilang jarak tempuhnya cukup jauh, Khaedar merasa terbebani dengan biaya yang sudah ditetapkan oleh pihak Grab. Menurutnya seharusnya pihak manajemen aplikasi Grab memberi potongan harga bagi penggunanya yang memiliki jarak tempuh yang cukup jauh.

Menurut penuturan Khaedar, promo/potongan harga yang biasa ditawarkan oleh pihak Grab memang membuatnya tergiur, tetapi promo/potongan harga tidak berlaku untuk semua layanan yang ditawarkan oleh pihak Grab. Hal ini dibuktikan ketika ingin menggunakan layanan GrabFood, Khaedar berharap promo yang ditawarkan muncul untuk pengguna GrabFood, tetapi ketika mengecek pada aplikasi Grab, promo yang ditawarkan hanya GrabBike saja. Sebagai pengguna transportasi online Grab, jaminan keamanan yang diinginkan oleh Khaedar yaitu atribut yang disediakan oleh pengendara GrabBike ketika sedang melayani, seperti helm standar SNI dan layak digunakan, jaket penanda bahwa pengendara GrabBike yang akan melayani merupakan pengendara/anggota Grab yang terdaftar, apalagi saat ini wabah/virus Corona dimana setiap orang yang berada diluar wajib menggunakan 
masker, hendaknya pihak manajemen dari Grab menyediakan masker gratis yang akan digunakan oleh pengguna layanan GrabBike.

Selama menggunakan layanan GrabFood, Khaedar pernah menemukan pengendara GrabFood yang kurang fokus saat sedang melayani, hal ini dibuktikan ketika Khaedar memesan minuman lebih dari satu, tetapi yang tiba tidak sesuai dengan jumlah pesanan yang dipesan. Menurut Khaedar, seharusnya pengendara GrabFood tersebut fokus terhadap apa yang diinginkan/dipesan oleh pengguna GrabFood, apalagi saat memesan semua pesanan yang diinginkan tercantum pada aplikasi. Menurut Khaedar sebagai pengguna transportasi online Grab, khususnya GrabFood ia menginginkan agar pelayanan yang diberikan lebih ditingkatkan lagi, seperti ketika memesan makanan/minuman, pengendara GrabFood yang melayani hendaknya menghubungi konsumen terkait pesanan yang diinginkan agar tidak terjadi kesalahan ketika memesan. Menurut Khaedar, pihak manajemen Grab perlu memberlakukan pembatasan jam operasional bagi pengendara/pengemudi Grab, dikarenakan selama menggunakan layanan Grab ia pernah memesan GrabCar diatas jam 11. Malam dan pengemudi GrabCar tersebut ternyata sudah lanjut usia. Menurut Khaedar hal tersebut sangat tidak wajar bagi seorang lanjut usia yang mencari nafkah, Khaedar sangat mengharapkan pihak manajemen Grab lebih memerhatikan lagi kondisi dari pengendara/pengemudi Grab itu sendiri.

Informan ketiga, menurut Arsil sejauh ini identitas dari pengendara/pengemudi transportasi online Grab sudah sangat memadai hal ini dibuktikan ketika ia sering kali menggunakan layanan GrabBike dan GrabFood dimana identitas pengendara Grab tersebut sama dengan yang ada dilapangan, selain itu plat kendaraan dan tipe/jenis kendaraan juga sama dengan yang ditampilkan pada aplikasi. Sedangkan dari segi atribut yang digunakan pengendara GrabBike, Arsil sering kali menemukan pengendara GrabBike yang atributnya bisa dibilang kurang layak untuk digunakan seperti helm yang digunakan tidak memiliki kaca pelindung yang dapat mengganggu mata selama berkendara. Menurut Arsil dari segi kondisi kendaraan yang digunakan oleh pengendara/pengemudi transportasi online Grab, masih terdapat beberapa kendaraan yang menurutnya kurang baik untuk digunakan. Hal ini dibuktikan dengan ketika Arsil sedang menggunakan layanan GrabBike ketika ingin kekampus, tetapi ditengah perjalanan kendaraan yang digunakan tersebut tiba-tiba mogok dikarenakan kehabisan bensin. Menurut penuturan pengendara GrabBikenya, ia tidak memerhatikan jarum bensin motornya saat itu. Menurut Arsil kesan pertama yang memberikan penilaian adalah dilihat dari sikap atau cara pengendara/pengemudi Grab yang terkesan ramah dan sopan. Sedangkan dari segi penampilan pengendara/pengemudi transportasi online Grab itu sendiri, Arsil tidak terlalu menilainya. Bagi Arsil, sikap profesionalisme yang dimiliki pengendara/pengemudi Grab yang menjadi penilaian lebih bagi Arsil sebagai pengguna transportasi online Grab. Menurut Arsil, tipe/jenis kendaraan yang digunakan oleh pengendara/pengemudi Grab yang menjadi daya tarik konsumen tidak terlalu memengaruhi dirinya sebagai pengguna transportasi online Grab. Menurut Arsil apapun tipe/jenis kendaraan yang digunakan oleh pengendara/pengemudi Grab itu sendiri, tidak menimbulkan unsur daya tarik bagi dirinya. Menurut Arsil sampai saat ini aplikasi Grab sudah sangat baik, hal ini dibuktikan ketika ia menggunakan layanan GrabExpress ketika mengirim barang, Arsil dapat melacak keberadaan barang tersebut selama proses pengiriman berlangsung.

Selama menggunakan GrabBike dan GrabCar, Arsil sangat jarang menemukan pengendara/pengemudi transportasi online Grab yang ugal-ugalan dalam berkendara. 
Menurut pengalaman Arsil sebagai pengguna Grab, ia kerap mendapatkan pengendara/pengemudi transportasi online Grab yang kurang cepat dalam melayani. Hal tersebut dibuktikan ketika Arsil menggunakan layanan GrabCar, selama diperjalanan lokasi yang ditempuh terbilang jauh dan selama diperjalanan area yang ditempuh terbilang cukup padat dan ramai, hendaknya pengendara GrabCar tersebut mencari jalur lain yang tidak terlalu padat dan ramai. Menurut Arsil selama menggunakan layanan transportasi online Grab, kesigapan/ketepatan pengendara/pengemudinya sudah sangat baik. Hal ini dibuktikan ketika Arsil menggunakan layanan GrabExpress, barang yang diantarkan tidak memakan waktu yang lama selama dalam perjalanan. Selama menggunakan layanan Grab, Arsil tidak pernah menghubungi pihak manajemen aplikasi Grab selama mengalami keluhan/kendala yang ia alami. Arsil hanya memberikan penilaian baik/buruknya pengendara/pengemudi Grab melalui aplikasi ketika memberi rating (bintang). Selama menggunakan layanan transportasi online Grab, Arsil tidak merasa terbebani dengan biaya yang sudah ditetapkan oleh pihak Grab, karena sejauh ini biaya yang sudah ditetapkan relatif terjangkau bagi dirinya. Menurut Arsil promo menjadi daya tarik bagi dirinya sebagai pengguna layanan Grab, apalagi setiap pekan arsil selalu berkumpul bersama keluarganya dan memesan makanan, baginya ia sangat terbantu dengan adanya promo/potongan harga yang ditawarkan oleh pihak manajemen Grab.

Sebagai pengguna transportasi online Grab, Arsil sangat mengandalkan jaminan keamanan yang diberikan oleh pihak manajemen Grab berupa asuransi bagi penggunanya ketika mengalami hal yang tidak diinginkan seperti kecelakaan. Selama menggunakan layanan Grab, sikap pengendara/pengemudi Grab sejauh ini sudah sangat baik dan ramah, hal ini dibuktikan ketika Arsil menggunakan layanan GrabBike, dimana pengendara GrabBike tersebut menanyakan tujuan yang hendak ditujui oleh Arsil, dan apakah ingin singgah ditempat lain atau tidak. Menurut Syarif sebagai pengguna transportasi online Grab, ia menginginkan agar pihak manajemen transportasi online Grab lebih memerhatikan kondisi/keadaan kendaraan yang digunakan oleh pengendara/pengemudi Grab. Pihak manajemen Grab harusnya lebih memerhatikan kondisi/kendaraan yang akan digunakan karena prioritas utama adalah keselamatan pengguna transportasi online Grab itu sendiri.

Menurut Syarif, pihak manajemen Grab perlu memberlakukan pembatasan jam operasional bagi pengendara/pengemudi Grab, apalagi melihat kondisi saat ini ketika pandemi mulai mewabah dan keperluan hidup semakin meningkat, banyak pengendara/pengemudi Grab yang rela bekerja diatas jam 12 malam, padahal hendaknya setiap orang berhak menjaga kesehatannya apalagi disaat pandemi ini. Pelaksanaan pelayanan transportasi online Grab yang baik merupakan keinginan semua penggunanya, oleh karena itu untuk menciptakan kepuasan penggunannya atas pelayanan yang diberikan, perusahaan atau pihak manajemen Grab tentunya harus mempersiapkan fasilitas yang nampak untuk dilihat dan dirasakan mulai dari identitas dan atribut pengendara/pengemudi Grab, kondisi kendaraan yang digunakan, penampilan pengendara/pengemudi Grab dan tipe/jenis kendaraan yang digunakan.

Berdasarkan dari hasil penyajian data pada dimensi bukti fisik dalam pelayanan transportasi online Grab, dimana bukti fisik pada kajian ini meliputi identitas (tanda pengenal) dan atribut pengendara/pengemudi Grab yang dinilai cukup baik, kondisi kendaraan pengendara/pengemudi Grab yang dinilai kurang baik, penampilan pengendara/pengemudi Grab yang dapat memengaruhi pelayanan dan memberikan kesan penilaian bagi pengguna Grab yang dinilai cukup baik, dan 
tipe/jenis kendaraan yang digunakan oleh pengendara/pengemudi Grab yang menjadi daya tarik pengguna Grab yang dinilai cukup baik.

Kemampuan perusahaan Grab dalam menunjukkan eksistensinya kepada para pelanggannya dengan penampilan, kemampuan sarana dan prasarana fisik perusahaan yang dapat diandalkan keadaan lingkungan sekitarnya merupakan bukti nyata dari pelayanan yang diberikan oleh pemberi jasa. Berkenaan dengan bukti fisik dari layanan yang diberikan oleh perusahaan Grab, mulai dari peralatan/perlengkapan, sumber daya manusia dan materi komunikasi perusahaan yang dinilai sudah cukup baik dan dengan adanya bukti fisik tersebut tentu hal itu sangat dibutuhkan bagi suatu perusahaan. Hal ini juga telah diperjelas oleh Parasuraman (2001:32) bahwa bukti fisik dalam kualitas pelayanan adalah bentuk aktualisasi nyata secara fisik dapat terlihat atau digunakan oleh masyarakat sesuai dengan penggunaan dan pemanfaatannya yang dapat dirasakan membantu pelayanan yang diterima oleh orang yang menginginkan pelayanan, sehingga puas atas pelayanan yang dirasakan, yang sekaligus menunjukkan prestasi kerja atas pemberian pelayanan yang diberikan.

Keandalan merupakan suatu pondasi bagi perusahaan yang juga harus diperhatikan didalam menyediakan pelayanan yang terpercaya dan akurat. Kinerja perusahaan maupun mitra Grab harus mampu sesuai dengan harapan pelanggan tanpa adanya kesalahan. Keandalan untuk melaksanakan jasa yang dijanjikan dengan terpercaya dan akurat yang dimana dari hasil penyajian data keandalan pada kajian ini meliputi aplikasi Grab ditinjau dari segi penggunaan aplikasi dan pelayanan jasanya yang dinilai sangat baik, pengendara/pengemudi mentaati peraturan/tata tertib dalam berlalu lintas yang dinilai cukup baik, dan waktu tempuh pelayanan pengendara/pengemudi Grab yang dinilai masih kurang baik. Setiap pelayanan memerlukan bentuk pelayanan yang handal, artinya dalam memberikan pelayanan perusahaan Grab dituntut untuk memiliki kemampuan baik secara manajerial maupun secara teknis untuk tetap melakukan inovasi yang sangat dibutuhkan oleh pengguna layanan transportasi online Grab. Setiap pelayanan memerlukan bentuk pelayanan yang handal, artinya dalam memberikan pelayanan, setiap pegawai diharapkan memiliki kemampuan dalam pengetahuan, keahlian, kemandirian, penguasaan dan profesionalisme kerja yang tinggi, sehingga aktivitas kerja yang dikerjakan menghasilkan bentuk pelayanan yang memuaskan, tanpa ada keluhan dan kesan yang berlebihan atas pelayanan yang diterima oleh masyaraka

Daya tanggap merupakan kemampuan yang dilakukan oleh pihak perusahaan dan mitranya dalam memberikan pelayanan dengan cepat dan tanggap. Daya tanggap dapat menumbuhkan persepsi positif terhadap kualitas jasa yang diberikan, termasuk didalamnya jika terjadi kegagalan atau keterlambatan dalam penyampaian jasa. Pihak perusahaan Grab sejauh ini berusaha memperbaiki atau meminimalkan kerugian pengguna jasa Grab dengan segera. Dimensi ini menekankan pada perhatian dan kecepatan perusahaan yang terlibat untuk menanggapi segala permintaan, pertanyaan, dan keluhan dari masyarakat. Berdasarkan hasil penyajian data daya tanggap pada kajian ini meliputi kesigapan/ketepatan pengendara/pengemudi Grab ketika sedang melayani yang dinilai sangat baik serta pihak manajemen aplikasi Grab sigap dalam merespon dan memberi solusi terkait keluhan pengguna selama menggunakan layanannya yang dinilai cukup baik.

Suatu organisasi sangat menyadari pentingnya kualitas pelayanan daya tanggap atas pelayanan yang diberikan. Setiap orang yang mendapat pelayanan sangat membutuhkan penjelasan atas pelayanan yang diberikan agar pelayanan 
tersebut jelas dan dimengerti. Untuk mewujudkan dan merealisasikan hal tersebut, maka kulitas layanan daya tanggap mempunyai peran penting atas pemenuhan berbagai penjelasan dalam kegiatan pelayanan pengguna jasa transportasi online Grab. Apabila pelayanan daya tanggap diberikan dengan baik, penjelasan yang mendetail, serta penjelasan yang mengarahkan, apabila hal tersebut secara jelas dimengerti oleh individu yang mendapat pelayanan, maka secara langsung pelayanan daya tanggap dianggap berhasil dan ini menjadi suatu bentuk keberhasilan prestasi kerja.

Seperti yang dikemukakan oleh Parasuraman (2001:52) bahwa setiap karyawan dalam memberikan bentuk-bentuk pelayanan, mengutamakan aspek pelayanan yang sangat memengaruhi perilaku orang yang mendapatkan pelayanan, sehingga diperlukan kemampuan daya tanggap dari pegawai untuk melayani masyarakat sesuai dengan tangka penyerapan, pengertian, ketidaksesuaian atas berbagai hal bentuk pelayanan yang tidak diketahuinya. Hal ini memerlukan adanya penjelasan yang bijaksana, mendetail, membina, mengarahkan dan membujuk agar menyikapi segala bentuk-bentuk prosedur dan mekanisme kerja yang berlaku dalam suatu organisasi, sehingga bentuk pelayanan mendapat respon positif.

Pelaksanaan jaminan merupakan hal yang penting diatur dalam perusahaan Grab, sebab dengan adanya jaminan yang diberikan oleh perusahaan Grab kepada penggunanya, maka hal itu akan memberikan rasa aman dan bebas dari bahaya. Dari hasil penyajian data jaminan pada kajian ini meliputi biaya/tariff yang dikenakan yang dinilai sangat baik, promo/potongan harga menjadi daya tarik konsumen yang dinilai sangat baik dan jaminan keamanan yang diinginkan oleh pengguna transportasi online Grab yang dinilai cukup baik. Melihat pelayanan yang diberikan oleh perusahaan Grab, telah memberikan berbagai bentuk jaminan kepastian yang tentu saja hal tersebut akan memberikan dampak kepada adanya rasa kepuasan dari para pengguna transportasi online Grab.

Hal ini juga telah dikemukakan oleh Parasuraman (2001) bahwa: segala bentuk urusan pelayanan yang dilakukan atas tuntas dan selesai sesuai dengan kecepatan, ketepatan, kemudahan, kelancaran dan kualitas pelayanan yang diberikan, setiap bentuk pelayanan memerlukan adanya kepastian atas pelayanan yang diberikan sehingga orang yang menerima pelayanan merasa puas.

Berdasarkan hasil kajian ini menunjukkan bahwa dari kelima dimensi kualitas pelayanan, pada umumnya memiliki hasil yang berada pada kategori cukup yaitu dimensi bukti fisik (tangibles), keandalan (reliability) dan empati (emphaty), satu dimensi berada pada kategori baik yaitu dimensi daya tanggap (responsiviness) dan satu dimensi berapa pada kategori sangat baik yaitu dimensi jaminan (assurance). Jadi dapat dikatakan bahwa sejauh ini perusahaan Grab dapat dikatakan cukup baik dalam memberikan pelayanan yang berkualitas dimana hal tersebut tentunya berdampak pada kepuasan pengguna/konsumennya khususnya bagi mahasiswa Fakultas Ekonomi Universitas Negeri Makassar yang menggunakan layanan transportasi online Grab.

Sikap empati merupakan suatu perasaan dalam diri seseorang yang sesuai dengan apa yang dirasakan oleh orang lain secara psikologis. Empati memiliki beberapa fungsi yang dapat membantu seseorang dalam bersosial, berinteraksi, berkomunikasi dan bersikap dilingkungan masyarakat. Perilaku yang muncul dari pengendara/pengemudi Grab terhadap pengguna/konsumennya berbeda-beda, hal ini terkait dengan kemampuan empati pengendara/pengemudi itu sendiri, adapun yang mempengaruhi kemampuan empati, yaitu pikiran yang optimis, tingkat pendidikan, 
keadaan psikis, pengalaman, usia, jenis kelamin, latar belakang, sosial budaya dan status sosial.

Dari hasil penyajian data empati pada kajian ini meliputi sikap pengendara/pengemudi Grab selama melayani yang dinilai cukup baik, standar pelayanan apa yang mesti ditingkatkan oleh pihak manajemen transportasi online Grab yang dinilai cukup baik dan perlu diberlakukannya pembatasan jam operasional bagi pengendara/pengemudi Grab yang dinilai cukup baik. Kemampuan empati terkadang memang tidak dapat langsung muncul dari diri seseorang begitu saja, melainkan empati dapat muncul karena adanya faktor dari pengguna itu sendiri yang menggunakan layanan transportasi online Grab. Setiap kegiatan atau aktivitas pelayanan memerlukan adanya pemahaman dan pengertian dalam kebersamaan asumsi atau kepentingan terhadap suatu hal yang berkaitan dengan pelayanan. Seperti yang dikemukakan oleh Parasuraman (2001:40), bahwa pelayanan akan berjalan dengan lancar dan berkualitas apabila setiap pihak yang berkepentingan dengan pelayanan memiliki adanya rasa empati dalam menyelesaikan, mengurus dan memiliki komitmen yang sama terhadap pelayanan.

\section{KESIMPULAN}

Berdasarkan hasil kajian tersebut, dari kelima dimensi kualitas pelayanan, pada umumnya memiliki hasil yang berada pada kategori cukup yaitu dimensi bukti fisik (tangibles), keandalan (reliability) dan empati (emphaty), satu dimensi berada pada kategori baik yaitu dimensi daya tanggap (responsiviness) dan satu dimensi berapa pada kategori sangat baik yaitu dimensi jaminan (assurance). Jadi dapat dikatakan bahwa sejauh ini perusahaan Grab cukup baik dalam memberikan pelayanan yang berkualitas dan hal tersebut tentunya berdampak pada kepuasan pengguna/konsumennya khususnya bagi mahasiswa Fakultas Ekonomi Universitas Negeri Makassar yang menggunakan layanan transportasi online Grab.

\section{DAFTAR PUSTAKA}

Ali, Irawati Ismail dkk. 2017. Makassar Smart Transportation: Penerapan Mamminasata Apps dan Mamminasata Card Guna Optimalisasi Bus Rapid Transit (BRT) Kota Makassar. Vol. 14, No. 1. Hal: 1-13.

Anwar, Ahsani Amalia. 2017. Online vs Konvensional: Keunggulan dan Konflik Antar Moda Transportasi di Kota Makassar. Vol. 2, No. 2. Hal: 220-246.

Cristalino, Franco. 2016. Analisis Indeks Kepuasan Masyarakat (IKM) Peminta Izin Mendirikan Bangunan (IMB) pada Dinas Pekerjaan Umum Kabupaten Katingan. Vol. 5, No. 1. Hal: 20-38.

Daryanto., dan Setyobudi Ismanto. 2014. Konsumen dan Pelayanan Prima. Yogyakarta: Penerbit Gava Media. https://kbbi.kemdikbud.go.id/entri/kua litas

Kadir, Abdul. 2006. Transportasi: Peran dan Dampaknya dalam Pertumbuhan Ekonomi Nasional. Vol. 1, No. 3. Hal: 121-131.

Marlius, Doni. 2017. Loyalitas Nasabah Bank Nagari Syariah Cabang Bukittinggi Dilihat Dari Kualitas Pelayanan. Vol. 1. No. 3. Hal: 237-250.

Miro, Fidel. 2012. Pengantar Sistem Transportasi. Jakarta: Penerbit Erlangga.

Mundir, Abdillah. 2015. Strategi Pemasaran Jasa Pendidikan Madrasah. Vol. 7, No. 1. Hal: 27-40. 
Panjaitan, Januar Efendi., dan Ai Lili Yuliati. 2016. Pengaruh Kualitas Pelayanan terhadap Kepuasan Pelanggan pada JNE Cabang Bandung. Vol. 11. No. 2. Hal: 265-289.

Parasuraman, A. Valerie. 2001. Delivering Quality Service. (diterjemahkan oleh Sutanto). New York: The Free Press.

Puspaningtyas, Meinarti. 2011. Analisis Strategi Pemasaran Jasa. Vol. 2, No. 1. Hal: 57-75.

Sangadji, Etta Mamang dan Sopiah. 2013. Perilaku Konsumen. Yogyakarta: Penerbit Andi.

Sari, Dessica Dinar., dan Utama Agung. 2016. Analisis Pengaruh Kualitas Produk, Kualitas Pelayanan dan Harga Terhadap Kepuasan Konsumen (Studi Kasus pada Konsumen SIM Card GSM Prabayar XL di Kota Yogyakarta). Vol. 5, No. 1. Hal: $62-72$.

Setiadi, Nugroho J. 2003. Perilaku Konsumen. Konsep dan Impilkasinya untuk Strategi dan Kajian Pemasaran. Jakarta: Kencana.

Susanti, Anita., Ria Asih Aryani Soemitro., dan Hitapriya Suprayitno. 2018. Identifikasi Kebutuhan Fasilitas bagi Penumpang di Stasiun Kereta Api Berdasarkan Analisis Pergerakan Penumpang. Vol. 2, No. 1. Hal: 23-34.

Sumarwan, Ujang. 2011. Perilaku Konsumen: Teori dan Penerapannya dalam Pemasaran. Bogor: Ghalia Indonesia.

Syarifuddin, Muhammad Fauzy., Mochammad Al Musadieq., dan Edy Yulianto. 2016. Pentingnya Pelabuhan Tanjung Perak Bagi Perekonomian Jawa Timur (Studi pada PT. Pelindo III Tanjung Perak Surabaya). Vol. 35, No.1. Hal: 172-178.

Tjiptono, Fandy. 2014. Pemasaran Jasa. Yogyakarta: Penerbit Andi.

Wendi, Eko Jundri., dan Yurni Suasti. 2018. Segmentasi Pasar Angkutan Bendi di Kota Solok. Vol. 2, No. 3. Hal: 806- 816. 